\title{
O ESTATUTO DA CIDADE E A DEMOCRATIZAÇÃO DA GESTÃO URBANA: UM ESTUDO DE CASO NA CIDADE DE MARABÁ - PA
}

\section{THE CITY STATUTE AND THE DEMOCRATIZATION OF URBAN MANAGEMENT: A CASE STUDY IN THE CITY OF MARABÁ - PA}

\author{
Daniella Maria dos Santos Dias ${ }^{1}$ \\ Chaira Lacerda Nepomuceno ${ }^{2}$
}

\begin{abstract}
Resumo
O presente artigo tem por objetivo avaliar o plano diretor participativo do município de Marabá quanto à missão de democratizar a gestão urbana, por meio de análise de documentos gerados em seus principais canais de comunicação com a sociedade, o "Conselho Gestor" e a "Conferência Municipal das Cidades". Para realizar o estudo de caso proposto, utilizou-se um roteiro com seis tópicos, baseados em dispositivos do Estatuto da Cidade. Conduziu-se uma pesquisa qualitativa, que se assume como particularística, com tendência descritiva e método de abordagem dedutivo. É cediço que o Estatuto da Cidade representou um grande avanço na legislação urbanística, regulamentando a política urbana constitucional. O plano diretor, instrumento de planejamento urbano, também previsto na Constituição Federal e regulamentado pelo Estatuto, obrigatório para cidades com mais de 20.000 habitantes, propõe uma mudança de paradigma, de um planejamento centrado no tecnicismo e burocracia, para um planejamento urbano participativo, includente e democrático. A obrigatoriedade de implantação, porém, não foi suficiente para promover esse horizonte. Extraiu-se da análise, a imprescindibilidade de concretizar os instrumentos contidos no plano diretor municipal, especialmente no que tange à democracia urbana, dar publicidade aos atos e documentos, e considerar, em revisão, a ampliação da participação popular no Conselho Gestor.
\end{abstract}

Palavras-chave: "Estatuto da Cidade"; "democracia urbana"; "plano diretor"; "planejamento urbano"; "estudo de caso".

\begin{abstract}
The purpose of this article is to evaluate Marabá's participative master plan in its mission to democratize urban management, through documentary analysis its main communication channels with society, the "Management Council" and the "Municipal Conference of the Cities ". To carry out the proposed case study, it was necessary a script with six topics, based on issues of the City Statute. It was conducted a qualitative research, particularistic, with a descriptive tendency and a deductive approach. The Statute of the City represented a major advance in urban legislation, regulating urban constitutional policy. The master plan, an instrument of urban planning, also provided for in the Federal Constitution and regulated by the Statute, obligatory for cities with more than 20,000 inhabitants, proposes a paradigm shift, from a planning centered on technicism and bureaucracy, to participatory, inclusive and democratic urban planning. The obligatory

\footnotetext{
${ }^{1}$ Pós-Doutorado pela Universidade Carlos III de Madri na Espanha, junto ao Departamento de Direito Público Comparado e ao Instituto Pascual Madoz. Professora da Universidade Federal do Pará (Graduação e PósGraduação). E-mail: diasdaniella@gmail.com

2 Estudante de Graduação em Direito na Unifesspa, participante no projeto de pesquisa "Planejamento e Desenvolvimento Urbano em Marabá - PA", desenvolvido na Faculdade de Direito. E-mail: chaira01@gmail.com
} 
implementation, however, was not enough to further this horizon. From the analysis, it was essential to achieve the instruments contained in the municipal director plan, especially with regard to urban democracy, to publicize acts and documents, and to consider, in review, the expansion of popular participation in the "Management Council".

Keywords: "The City Statute"; "urban democracy"; "Master Plan"; "urban planning"; "case study". 


\section{INTRODUÇÃO}

A redemocratização do país e a promulgação de uma nova Constituição em 1988 (CR/88) assinalaram um cenário de imprescindibilidade da participação popular na tomada de decisões políticas, assumindo o cidadão brasileiro o papel de partícipe ativo do exercício do poder democrático (ASSUNÇÃO, 2013, p. 48).

Ainda no Artigo 1으, parágrafo único, do texto constitucional, assegurou-se que "todo poder emana do povo, que o exerce por meio de representantes eleitos ou diretamente, nos termos desta Constituição", abrindo a possibilidade do exercício democrático direto e, do mesmo modo, a ampliação da participação política. Assim como, buscou-se o fortalecimento do poder de influência dos atores sociais através das chamadas "iniciativas populares" 3 .

A República Federativa do Brasil também consagrou na Carta Constitucional a cidadania e a dignidade da pessoa humana como seus fundamentos ${ }^{4}$ (art. 1으, II e III), princípios estes que se autoimplicam, de tal modo que a dignidade humana "necessita ser densificada por meio de processos democráticos que permitam o efetivo exercício de cidadania" (DIAS, 2010, p. 254). Essa estreita relação se justifica na medida em que é na vida pública e em espaços democráticos que a dignidade humana toma expressão, por meio da autodeterminação e "autonomia pessoal do sujeito moral, em tomar parte de diálogos e na tomada de decisões sobre os rumos do processo político" (DIAS, 2010, p. 198).

Note-se que "o próprio conceito de cidadania se apresenta ampliado, revestido de algo maior que o mero direito de votar e de ser votado; passa a ser parâmetro de regência dos relacionamentos sociais, de atuação e de cooperação popular nas instituições estatais" (SILVA, 2006, p. 120), pois é a partir do exercício de cidadania que o indivíduo contribuirá para o fortalecimento do Estado Democrático de Direito. Assim, "sob essa perspectiva, o conteúdo democrático é transformador na medida em que propõe a igualdade, a melhoria das condições existenciais dos cidadãos e a realização da dignidade humana, partindo do fomento às práticas decisórias democráticas públicas" (DIAS, 2012, p. 63).

\footnotetext{
${ }_{3}^{3}$ Por meio do Artigo 14, garantiu-se a iniciativa popular como propulsora de processos legislativos. O Artigo 29, sobre a organização das cidades, por sua vez, estabeleceu a participação dos representantes de associações populares no processo de organização destas primeiras.

${ }^{4}$ Partilhados como fundamentos do Estado, cidadania e democracia são artífices indispensáveis para o fortalecimento da transparência dos atos públicos tanto de gestão como nos processos de elaboração das leis. Fortalecem a accountability social, como uma importante ferramenta no controle da Administração Pública no gerir as políticas públicas e no direcionar o uso dos recursos públicos (AMARAL; GUIMARÃES; DAUMERIE, 2015, p. 812).
} 
Por outro lado, afirmam Santos; Avritzer (2002, p. 59) "que as sociedades capitalistas, sobretudo nos países centrais, consolidaram uma concepção hegemônica de democracia, [...] com a qual procuraram estabilizar a tensão controlada entre democracia e capitalismo". E essa estabilização teria ocorrido por duas vias: pela prioridade conferida à acumulação de capital em relação à redistribuição social e pela limitação da participação cidadã, tanto individual quanto coletiva, com o objetivo de não "sobrecarregar" demais o regime democrático com demandas sociais que pudessem colocar em perigo a prioridade da acumulação sobre a redistribuição.

No que tange à limitação da participação cidadã, a economia do capitalismo de mercado gera desigualdades nos recursos políticos a que os diferentes cidadãos têm acesso, ou seja, "cidadãos economicamente desiguais têm grande probabilidade de ser também politicamente desiguais" (DAHL, 2001, p. 175). Isso se reflete de tal forma que, em uma economia capitalista, torna-se, pois, "impossível atingir a plena igualdade política" (DAHL, 2001, p. 175). Por isso, no fundo, é quase certo que "a tensão entre os objetivos democráticos e uma economia capitalista de mercado continue indefinidamente" (DAHL, 2001, p. 201).

Por conseguinte, "quanto mais se insiste na fórmula clássica da democracia de baixa intensidade, menos se consegue explicar o paradoxo de a extensão da democracia ter trazido consigo uma enorme degradação das práticas democráticas" (SANTOS; AVRITZER, 2002, p. 42), degradação demonstrada pelo crescente abstencionismo eleitoral e pela patologia da representação, caracterizada pelo fato de os cidadãos se considerarem cada vez menos representados por aqueles que elegeram.

De fato, Purcell (2013, p. 313) menciona que as atuais práticas democráticas se aproximam mais de uma oligarquia, na medida em que a democracia num Estado Liberal consiste numa instituição onde um pequeno grupo de pessoas é selecionado, separado do restante da população e designado para governar o todo ${ }^{5}$.

Quanto a este pequeno grupo, Dahl (2001, p. 128) afirma que sob um governo representativo, muitas vezes os cidadãos "delegam imensa autoridade arbitrária para decisões de importância extraordinária", não apenas a seus representantes eleitos, mas também a "administradores, burocratas, funcionários públicos, juízes e, em grau ainda maior, a organizações internacionais" (DAHL, 2001, p. 128). Mike Davis (2006), em sua obra "Planeta Favela", traz à luz a

\footnotetext{
${ }^{5}$ However, in truth the liberal democratic state is an institution in which a relatively few people are selected, separated out from the population, and designated to govern the whole.
} 
existência de uma democracia virtual, em que, em especial os países de terceiro mundo, são governados pelas políticas do Banco Mundial.

Diante do cenário de degradação das práticas democráticas, com a prevalência de um governo de poucos em detrimento da maioria, imiscuído de patologias que alijam o povo do processo decisório, Purcell questiona, o que democracia significa? (PURCELL, 2013, p. 315).

Democracia é um modo de vida em sociedade no qual as pessoas gerenciam, elas mesmas, suas condições de existência. Na democracia, pessoas são autônomas ao invés de heterônomas e governam por si mesmas, não pela lei dada a elas por outros. Definir sua própria lei não pode ser nunca um estado passivo de descanso, sim um projeto em contínua atividade . $^{6}$

Robert Dahl (2001, p. 19) afirma que "a democracia pode ser inventada e reinventada de maneira autônoma sempre que existirem as condições adequadas". Significa dizer que, existe a necessidade de superação das limitações que o modo de produção impõe à maior parte da população, quando os exclui do processo democrático, na medida em que os desiguala politicamente, criando condições de exercerem sua autonomia, pedra fundamental de um regime democrático.

Enquanto não se atinge esse objetivo, subsistirá "o fato de a democracia referir-se ao mesmo tempo a um ideal e a uma realidade" (DAHL, 2001, p. 37), de tal modo que "em todos os países democráticos há uma grande lacuna entre a democracia real e a democracia ideal" (DAHL, 2001, p. 42)

Por isso, "dentre tantas reflexões acerca do Estado Democrático de Direito, destacam-se os estudos sobre as novas ondas das democracias, que avançaram muito, também em razão do desencantamento com a democracia representativa" (AMARAL; GUIMARÃES; DAUMERIE, 2015, p. 806).

Nesse cenário de descontentamento com nossos governantes, quem deveria nos administrar? Nós mesmos, questiona e tão prontamente responde Robert Dahl (2001, p. 89). Justifica ainda que, com poucas exceções, se "os adultos devem ter o direito de tomar decisões pessoais sobre o que é melhor para seus interesses, por que devemos rejeitar essa ideia no governo do Estado?" (DAHL, 2001, p. 90). Acrescentando a magistral lição de Bobbio (1997, p. 31), "a educação para a democracia surgiria no próprio exercício da prática democrática".

\footnotetext{
${ }^{6}$ Democracy is a mode of living together in which people manage for themselves the conditions of their own existence. In democracy people are autonomous rather than heteronomous, meaning literally that people are autonomous rather than having the 'law given to them by another'. In a democracy, people rule themselves; they are not ruled by others. Rulling oneself is an active project; it is never a passive state of rest.
} 
Ganham espaço, então, "as experiências políticas que assumiram o nome de democracia participativa, [que] em geral, se opõem ou buscam complementar as formas de democracia representativa" (SADER, 2002, p. 657). Procura-se, então, "na originalidade das novas formas de experimentação institucional, potenciais emancipatórios ainda presentes nas sociedades contemporâneas" (SANTOS; AVRITZER, 2002, p. 77).

O desígnio da democracia participativa é reavivar a importância das pessoas se interessarem pelo que acontece no "palácio" (BOBBIO, 1997, p. 32), daí que, "o modelo participativo apresenta-se, então, como um caminho aberto, prenhe de possibilidades a incluir os cidadãos no processo decisório e também resgatar a legitimidade das instituições democráticas numa sociedade global, com contrastes e contradições" (DIAS, 2010, p. 208).

Entretanto, é evidente que se por democracia direta se entende "a participação de todos os cidadãos em todas as decisões a eles pertinentes", a proposta torna-se insensata. Pois, esperar "que todos decidam sobre tudo em sociedades mais complexas, como são as modernas sociedades industriais, é algo materialmente impossível" (BOBBIO, 1997, p. 42).

Para que a proposta da democracia participativa seja exequível - estando os municípios mais próximos do cidadão, constituindo a esfera da federação em "que as relações entre Estado e Sociedade se processam de forma mais direta e próxima", - torna-se, então, o nível local "o locus político ideal em que a participação popular pode efetivamente ser estabelecida como requisito do planejamento e da gestão pública" (PRIETO, 2010, p. 50), "botando em questão o padrão disponível de relação entre Estado e sociedade e introduzindo elementos de renovação cultural" (AVRITZER, 2002, p. 571).

Destarte, fez-se necessário esse arcabouço teórico para relacionar a importância de experimentação de novas formas de democracia, refletido em nosso ordenamento jurídico não somente na conjuntura da assembleia constituinte de 1988, após um longo jejum democrático (conforme já fora mencionado), como também no contexto de inclusão do capítulo referente à política urbana, que segundo Trindade (2012, p. 145) representou uma "conquista histórica de um conjunto de movimentos e organizações populares alinhados ao tema da reforma urbana no Brasil e foi fruto de um processo de mobilização social e política", que se iniciou nos anos 60. Após golpe militar em 1964, a temática ficou adormecida, até voltar à tona com a formação da assembleia constituinte em 1988, quando dessas articulações originou-se o Movimento Nacional pela Reforma Urbana (MNRU). 
O MNRU apresentou uma emenda constitucional denominada Emenda Popular de Reforma Urbana, subscrita por cerca de 130 mil eleitores. Em que pese não ter sido incorporada em sua totalidade, "pela primeira vez na história constitucional brasileira havia um capítulo específico sobre política urbana, localizado nos artigos 182 e 183, os quais continham o princípio da função social da cidade e da propriedade urbana" (TRINDADE, 2012, p. 145).

Daí que o Estatuto da Cidade $(E C)$ representou um grande avanço na legislação urbanística brasileira, cumprindo, além da missão de regulamentar a política urbana de nossa Constituição cidadã (ainda que 13 anos após sua promulgação), também de aproximar a gestão municipal do cidadão, por meio da previsão de vários instrumentos de democracia participativa, para construção de um ideal comum de cidade, pois conforme aduz Harvey (2014, p. 20), "o direito à cidade é um significante vazio. Tudo depende de quem Ihe vai conferir significado".

Trindade (2012, p. 150) acrescenta que o "direito à cidade somente se justifica do ponto de vista jurídico na perspectiva da função social da propriedade urbana". Nesse sentido, em seu art. 1o, parágrafo único, o Estatuto da Cidade esclarece a necessidade de pensar conjuntamente esses conceitos, quando estabelece "normas de ordem pública e interesse social que regulam o uso da propriedade urbana em prol do bem coletivo, da segurança e do bem-estar dos cidadãos, bem como do equilíbrio ambiental", e quando organiza os dispositivos jurídicos-institucionais de que deve valer-se o Estado para regular o uso e ocupação do solo.

De todo modo, "deve ser lembrado também que o Estatuto da Cidade não se baseia unicamente no princípio da função social da propriedade" (TRINDADE, 2012, p. 150). Este diploma legal introduziu a obrigatoriedade de participação popular na elaboração do Plano Diretor, não apenas como uma opção política, tal qual o caso das leis orçamentárias.

É assim, por meio do Plano Diretor, instrumento de planejamento urbano contido no texto constitucional e regulamentado pelo Estatuto, que se propõe uma mudança de paradigma: de um planejamento centrado no tecnicismo e burocracia, para um planejamento urbano participativo, includente e democrático.

Esta abordagem teórica inicial vem justificar o objetivo deste trabalho, de avaliar o Plano Diretor Participativo do Município de Marabá (PDPMM), no estado do Pará, em seu último ano de vigência, quanto ao seu grau de desenvolvimento e maturidade dos processos participativos previstos e implantados e sua missão de democratizar a gestão urbana municipal. Assim como, têm-se por objetivos específicos deslindar a efetividade do PDPMM na inclusão e participação 
social e seu potencial emancipatório para o exercício da cidadania, assim como aferir as possibilidades do munícipe em influenciar nos processos decisórios da gestão urbana municipal.

Foi desenvolvida uma pesquisa de natureza qualitativa, cujas fontes principais são a pesquisa bibliográfica e a pesquisa documental no âmbito dos principais canais de comunicação do Plano Diretor Participativo do Município de Marabá com a sociedade: o Conselho Gestor e a Conferência Municipal das Cidades. A proposta é a realização de um estudo de caso, no sentido de uma investigação que se assume como particularística, com tendência descritiva, com método de abordagem dedutivo. Este estudo encontra-se no escopo do projeto de pesquisa "Planejamento e Desenvolvimento Urbano em Marabá - PA", desenvolvido na Faculdade de Direito da Universidade Federal do Sul e Sudeste do Pará (UNIFESSPA), sob orientação da Professora Dra. Daniella Maria dos Santos Dias.

\section{O DIREITO URBANÍSTICO NO ORDENAMENTO JURÍDICO BRASILEIRO E A RENOVAÇÃO PARADIGMÁTICA DOS INSTRUMENTOS PARTICIPATIVOS DE GESTÃO MUNICIPAL}

A partir da Constituição de 1988 adotou-se um desenho federativo voltado à expandir as competências da esfera local de governo, o que possibilitou significativos avanços à descentralização na elaboração e evolução das políticas públicas. Essa descentralização coincidiu também com a busca de democracia e liberdade, assim como espelhou o que a sociedade almejava após um longo período de ditadura militar.

Igualmente, o sistema federativo proveu os municípios de poderes de auto-organização e autoadministração que, aliados à proximidade com a população, passaram a ser vistos como "ambientes" mais propícios ao diálogo e à participação da sociedade nos processos decisórios, porquanto também são os locais onde se verifica maior conflito entre a vontade política e as necessidades da população, afinal, mora-se no município.

A Carta Magna também delegou aos municípios competência para atuar na área urbanística por meio dos artigos 182 e 183, normas constitucionais de eficácia limitada. O artigo 182, caput, descreve que "a política de desenvolvimento urbano executada pelo Poder Público municipal, conforme diretrizes gerais fixadas em lei, tem por objetivo ordenar o pleno desenvolvimento das funções sociais da cidade e garantir o bem-estar de seus habitantes" (BRASIL, 1988). Esses dispositivos foram posteriormente regulamentados pela Lei $n^{\circ} 10.257 / 2001$, o "Estatuto da Cidade", com o desígnio de promover o direito à cidade, contendo os efeitos 
deletérios de um processo de urbanização acelerado, fortemente influenciado pelo mercado imobiliário, dotando o Poder Público de instrumentos jurídicos para tanto.

No que tange o processo de urbanização, Rolnik (2012, p. 20) compara a cidade a um imã, e que essa atração exercida pelo urbano, implica em apreender a vida de maneira coletiva. Entretanto, em analogia ao imã, a cidade aparentemente está dividida em polos, ou melhor dizendo, zonas. Onde cada qual tem seu lugar e a este "movimento de separação das classes sociais e funções no espaço urbano que os estudiosos da cidade chamam de segregação espacial" (ROLNIK, 2012, p. 45). Os territórios específicos para cada grupo social, a separação das funções de trabalhar e morar, a patente diferença de tratamento pela própria administração local, culminam na existência de muros invisíveis separando a cidade (ROLNIK, 2012). Essa diferença de tratamento pelo Poder Público não só reflete, como aprofunda a desigualdade, à medida que áreas bem estruturadas, dotadas de equipamentos urbanos, sofrem forte influência da especulação imobiliária, tornando-se mais distante para os menos afortunados, o sonho de "morar bem".

Em especial, nas grandes metrópoles brasileiras percebe-se "uma intensificação nas tendências segregatórias, excludentes e discriminatórias entre os grupos mais pobres e os mais endinheirados", que refletem no acirramento de disputas sociais por terras e conflitos fundiários (NAKANO, 2015, p. 20). Ao mesmo tempo que a população de baixa renda sobrevive em assentamentos precários nas periferias, são, da mesma forma, a quem menos se destinam as políticas públicas.

Tamanha complexidade dos problemas metropolitanos culminou com a aprovação da Lei no 13.089/2015, o Estatuto da Metrópole (NAKANO, 2015). Esta lei estabelece "diretrizes gerais para o planejamento, a gestão e a execução das funções públicas de interesse comum em regiões metropolitanas e em aglomerações urbanas" (BRASIL, 2015). O que se pretende é uma "ação conjunta das forças federativas no campo do desenvolvimento urbano, com base nos incisos XX do art. 21, IX do art. 23 e I do art. 24, no § 30 do art. 25 e no art. 182 da Constituição Federal" (BRASIL, 2015), superando velhos partidarismos e rixas políticas entre mandatos de municípios vizinhos, busca-se cultivar um ambiente de cooperação nesses centros, que rompem os limites políticos e geográficos. 
Em contraposição ao cenário fático, o que se busca por meio dos Estatutos, seja o EC ou o Estatuto da Metrópole7, é efetivar o direito à cidade, que, segundo Harvey (2014, p.28) é

mais do que um direito de acesso individual ou grupal aos recursos que a cidade incorpora; é um direito de mudar e reinventar a cidade mais de acordo com nossos mais profundos desejos. Além disso, é um direito mais coletivo do que individual, uma vez que reinventar a cidade depende inevitavelmente do exercício de um poder coletivo sobre o processo de urbanização.

Nesse viés, o Estatuto da Cidade atua impulsionando o poder público, entendam-se todos os entes políticos da Federação, "a lutarem por espaços urbanos mais qualitativos, menos excludentes, em que todos os cidadãos possam efetivamente vivenciar a sua cidadania" (DIAS, 2012, p. 54). Por isso, também optou por "mitigar a democracia representativa, ao estabelecer formas de participação direta e semidireta da população na gestão e na formulação de políticas públicas para as áreas urbanas" (DIAS, 2012, p. 66).

Isso porque, "a proposta que o Estatuto da Cidade vem trazer é de uma gestão urbana "concertada", em que o poder público tome decisões sobre os rumos do desenvolvimento urbano a partir da leitura e do diálogo com a população" (DIAS, 2012, p. 64). Viana (2014) reafirma que os instrumentos previstos no Estatuto da Cidade mostram que a administração não pode, nem deve administrar sozinha. O cidadão, por sua vez, pode e deve participar da formação da decisão administrativa, por meio dos instrumentos previstos naquele diploma legislativo.

Assim, em seu artigo 2o, está exposto neste diploma legal que a "política urbana tem por objetivo ordenar o pleno desenvolvimento das funções sociais da cidade e da propriedade urbana, mediante as seguintes diretrizes gerais (BRASIL, 2001)":

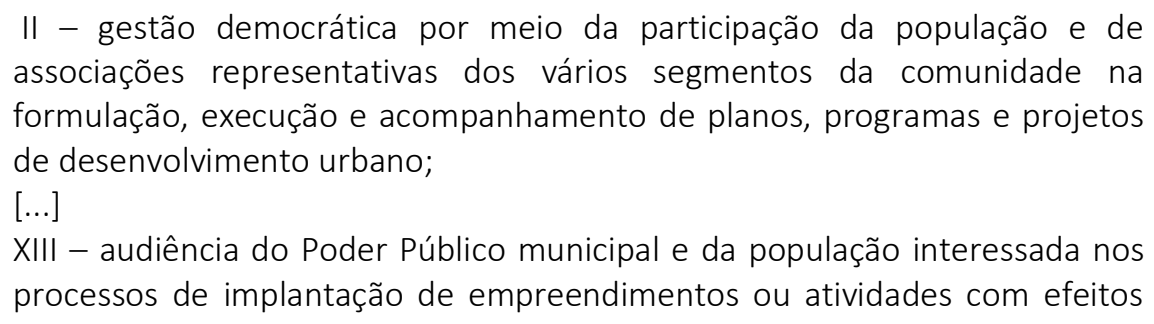
associações representativas dos vários segmentos da comunidade na formulação, execução e acompanhamento de planos, programas e projetos de desenvolvimento urbano;

$[\ldots]$

XIII - audiência do Poder Público municipal e da população interessada nos processos de implantação de empreendimentos ou atividades com efeitos

\footnotetext{
7 O Estatuto da Metrópole ratifica os princípios do EC em seu capítulo III, entre outros artigos, assim como reafirma a aplicação de normas gerais de direito urbanístico no artigo 1o, §2o; afinal, a metrópole também é uma cidade, que exauriu as fronteiras intermunicipais e políticas.

8 O movimento de consensualidade na Administração Pública se manifesta por meio dos fenômenos da concertação administrativa e da contratualização administrativa. A concertação traduz um método flexível de governar, por meio da interação entre representantes do Governo e de outros atores sociais, em busca do consenso. Já a contratualização administrativa "retrata a substituição das relações administrativas baseadas na unilateralidade, na imposição e na subordinação por relações fundadas no diálogo, na negociação e na troca" (VIANA, 2014, p. 1).
} 
potencialmente negativos sobre o meio ambiente natural ou construído, o conforto ou a segurança da população;

Significa dizer que o EC adotou, como princípio basilar da política urbana, a gestão democrática (II), com participação da população e associações de forma representativa, não apenas como simulacro democrático. Em virtude da axiologia da função social da propriedade e direito à cidade, não só na legislação infraconstitucional, como na própria Constituição, que no inciso XIII, privilegia-se a oitiva da população para implantação de empreendimentos ou atividades potencialmente agressivas ao meio ambiente, seja ele natural ou construído. Apreende-se que o EC optou por ponderar entre os supostos argumentos empregados na justificação de grandes empreendimentos, tais como suposta geração de empregos e circulação de renda, em claro apreço ao direito à cidade e à um meio ambiente equilibrado.

Do artigo 182, § 1ํㅡ, da Carta Maior extraiu-se também a obrigatoriedade do Plano Diretor para cidades com mais de 20 mil habitantes, definido como "instrumento básico da política de desenvolvimento e de expansão urbana". Esmiuçado no EC, é dedicado ao Plano Diretor um capítulo, que o relaciona diretamente ao cumprimento da função social da propriedade (artigo 39). Sobretudo, dado sua importância no planejamento municipal, deve estar ainda atrelado às políticas orçamentárias do município, tal qual preceitua o $§ 1$ 이o do art. 40.

Também houve um expressivo reconhecimento da importância da participação popular no plano diretor, que pode ser encarado como a mudança mais significativa na concepção do planejamento das cidades, em contraste com a visão convencional tecnocrática, excludente e formalista, verificada no artigo 40, $§ 4$ ㅇ desta Lei, que tornou obrigatória a participação popular em todas as fases de elaboração do plano, com a "promoção de audiências públicas e debates com a participação da população e de associações representativas dos vários segmentos da comunidade" (I), "a publicidade quanto aos documentos e informações produzidos" (II) e "o acesso de qualquer interessado aos documentos e informações produzidos" (III) (BRASIL, 2001).

Vale ressaltar que "este dispositivo legal vem dar densidade jurídica ao princípio da soberania popular, esculpido na Constituição Federal, e propõe a criação de uma nova forma de gestão da política urbana" (DIAS, 2012, p. 64).

Para que seja efetivamente participativo, o plano terá de ser elaborado com o auxílio e participação dos cidadãos, isto é, "como corolário do princípio democrático e da soberania popular, sob pena de ineficácia e nulidade" (DIAS, 2012, p. 129). A participação social e a gestão democrática tornaram-se, pois, "condições essenciais para o cumprimento dos objetivos maiores do plano diretor e da política urbana", assim como também são "elementos fundamentais no 
processo de elaboração do plano diretor, ou seja, desde os primeiros diagnósticos até a aprovação final dessa lei" (PRIETO, 2010, p. 44). Dessa forma, busca-se ir além da letra da lei, para a ideia de um plano diretor participativo, muito mais do que produto, um verdadeiro processo de planejamento das cidades.

Os novos ventos da democratização da gestão sopraram e influenciaram também a gestão orçamentária que, no âmbito municipal, deve ser participativa, conforme preconiza o artigo 44 do EC, o que pressupõe "a existência de debate, audiências e consultas públicas sobre as propostas do plano plurianual, da lei de diretrizes orçamentárias e do orçamento anual, como condição obrigatória sem a qual o orçamento municipal não será aprovado pela Câmara Municipal" (DIAS, 2010, p. 354).

À gestão democrática da cidade foi dedicado um capítulo do EC, que instituiu os seguintes instrumentos para sua concretização, em seu artigo 43:

I - órgãos colegiados de política urbana, nos níveis nacional, estadual e municipal;

II - debates, audiências e consultas públicas;

III - conferências sobre assuntos de interesse urbano, nos níveis nacional, estadual e municipal;

IV - iniciativa popular de projeto de lei e de planos, programas e projetos de desenvolvimento urbano; (BRASIL, 2001).

Ensejando uma efetiva e relevante participação nos instrumentos outrora citados, já combatendo as justificativas de exclusão da população dos processos decisórios, colmata-se o capítulo com o art. 45 , in verbis:

Os organismos gestores das regiões metropolitanas e aglomerações urbanas incluirão obrigatória e significativa participação da população e de associações representativas dos vários segmentos da comunidade, de modo a garantir o controle direto de suas atividades e o pleno exercício da cidadania (BRASIL, 2001).

Contudo, lamentavelmente, "há um descompasso entre as previsões normativas e a realidade cotidiana, em que não há adequação entre o ideal formal de participação cidadã e a cidadania tupiniquim" (MEIRELLES; GOMES, 2007, p. 166). Em outras palavras, "a cultura política brasileira e a falta de maturidade democrática do povo brasileiro têm representado obstáculos à efetividade do planejamento e gestão participativos regulados pelo Estatuto da Cidade" (SANTOS; FARIA; ARAÚJO, 2009, p. 226).

Também não basta apenas tornar obrigatória a elaboração do Plano Diretor (PD) para tornar os agentes públicos conscientes da importância do instrumento ao planejamento. Em geral, este instrumento é encarado como uma mera formalidade e não o resultado de um processo de planejamento. É visto como uma "exigência burocrática inútil, que apenas facilita a obtenção de 
recursos públicos" (OSCAR, 2014, p. 306). Além disso, a elaboração do plano diretor, na maioria das vezes, é capitaneada por empresas de consultoria e equipes estranhas à administração pública local, transformando-o num instrumento que não reflete as necessidades do local e/ou tende a se tornar inviável técnica e politicamente.

Marques; Alves (2015, p. 607) acrescentam que relativo ao exercício da cidadania e motivação para aderir aos mecanismos participativos, parte da população assume o papel de empregado do sistema produtivo, o qual ante a dificuldade de sobrevivência, possui pouco tempo para assumir um papel de cidadão mais ativo.

Estão resumidos a três os problemas de participação, no mapeamento de Abers (2000) apud Souza (2001), segundo o qual, o primeiro é o problema de implementação, isto é, mesmo quando os governos buscam implementar mecanismos participativos voltados para integrar grupos menos poderosos no processo decisório, os mais poderosos têm força para impedir essa participação. O segundo é o problema da desigualdade, mesmo quando espaços são criados para que todos participem, as desigualdades socioeconômicas tendem a criar obstáculos à participação de certos grupos sociais. O terceiro é o problema da cooptação, mesmo que os espaços de participação sejam genuinamente representativos, o desequilíbrio entre o governo e os participantes, no que se refere ao controle da informação e dos recursos, faz com que a participação seja manipulada pelos membros do governo.

Santos; Avritzer (2002, p. 75) colocam que a perversão do processo pode ocorrer por muitas outras vias, seja pela burocratização da participação, pela reintrodução de clientelismo sob novas formas, pela instrumentalização partidária, pela exclusão de interesses subordinados através do silenciamento ou da manipulação das instituições participativas, e concluem que "estes perigos só podem ser evitados por intermédio da aprendizagem e da reflexão constantes para extrair incentivos para novos aprofundamentos democráticos".

Avritzer (2002, p. 592) também mostra que as soluções para as questões centrais com as quais a democracia lida mudam de acordo com os diferentes cenários políticos. No caso brasileiro, "o clientelismo, a falta de capacidade de pressão da população e a distribuição desigual dos bens públicos em nível local são algumas das questões com as quais as formas fixas da democracia não são capazes de lidar de forma adequada" (AVRITZER, 2002, p. 592). Ocorre que, no Brasil, "a política torna-se uma atividade particular, exercida por profissionais, que constituem uma elite política, responsável pelo "gerenciamento" da sociedade através do Estado - este cada vez mais considerado como uma "empresa"” (SADER, 2002, p. 658). 
Todas essas máculas, no entanto, não devem justificar qualquer retrocesso no processo participativo, pois só surgiram problemas porque houve uma abertura à participação popular e, na maioria dos casos, pela primeira vez (PRIETO, 2010). "É certo que a instauração de práticas democráticas e de cidadania leva anos, até gerações, para obter resultados concretos, estabelecendo uma cultura de participação popular e gestão democrática" (PRIETO, 2010, p. 45). No domínio da democracia participativa, "mais do que em qualquer outro, a democracia é um princípio sem fim e as tarefas de democratização só se sustentam quando elas próprias são definidas por processos democráticos cada vez mais exigentes" (SANTOS; AVRITZER, 2002, p. 75).

Nakano (2015, p. 26) tece interessante crítica ao EC, ao afirmar que na verdade, o referido diploma legal "não disciplinou em detalhes o que seria essa gestão democrática, nem com critérios mínimos". Por conseguinte, serão apresentados no próximo tópico, os relatos de implantação do Plano Diretor Participativo em municípios brasileiros, que ilustram os vários óbices à concretização dos instrumentos previstos no Estatuto da Cidade listados nos parágrafos anteriores.

\section{RELATOS DE EXPERIÊNCIAS DE IMPLANTAÇÃO DE DESENHOS PARTICIPATIVOS EM MUNICÍPIOS BRASILEIROS}

Quando posto em prática, o paradigma de uma gestão urbana participativa estabelecido pelo Estatuto da Cidade esbarra nos entraves descritos no tópico anterior. Deste modo, serão relatadas algumas experiências de implantação do Plano Diretor Participativo em municípios brasileiros, o que se justifica para demonstrar os óbices fáticos à gestão democrática nos municípios brasileiros.

Note-se que, ainda que nos relatos não haja coincidência com a metodologia empregada neste artigo, em apertada síntese, baseiam-se todos no mesmo objetivo, qual seja, a avaliação de aspectos do Plano Diretor, no que tange ao atendimento às disposições da Lei no 10.257/2011.

Acrescentou-se uma pequena passagem sobre a experiência de implantação do Orçamento Participativo em Porto Alegre, para enriquecer com as contribuições de Boaventura de Souza Santos a respeito desse tema e listar também os entraves surgidos nesse percurso.

No município de Duque de Caxias (RJ), Oscar Jr. (2014) relatou que na implantação do Plano Diretor, o pouco tempo destinado à sua elaboração sacrificou etapas fundamentais para o desenvolvimento de um bom instrumento. Como reflexo disto, não se formou um conhecimento bem consolidado a respeito das características municipais, reforçando a essência "crescimentista" e não desenvolvimentista dos municípios. O autor constatou também que o PD não representou os 
interesses da sociedade local, não podendo receber a designação de participativo, uma vez que aos segmentos socialmente marginalizados restou a ocupação de ZEIS (zonas especiais de interesse social) implantadas em áreas frágeis do ponto de vista ambiental e carentes em termos de infraestrutura, concluindo-se, pois, que não tiveram voz ativa na elaboração das políticas públicas.

Fonseca; Belém; e Silva (2009) realizaram um estudo sobre a implantação do Plano Diretor em Paraisópolis, bairro carente da cidade de São Paulo (SP), localizado ao lado do bairro do Morumbi, área nobre. Os autores relatam que não houve uma construção do que iria ou não entrar na lei do Plano Diretor, nem na fase inicial da elaboração do projeto de lei, nem na fase de deliberação do texto final, embora fosse necessária a discussão pública e participativa. Mostram ainda que para que isto ocorresse, seria necessária uma qualificação para a discussão, ou seja, a capacitação dos moradores para o debate avançado em torno do texto e das propriedades a constarem no projeto. Desse modo, a hipossuficiência técnica dos moradores resultou legitimadora em um plano de urbanização excludente.

Coriolano; Rodrigues; Oliveira (2013) realizaram uma análise do Plano Diretor de Palmas (TO). Segundo os autores, a lei previa uma densidade mínima de 300 habitantes por hectare, racionalizando a implantação da infraestrutura. Apesar de ficar clara a intenção de promover uma ocupação ordenada e sequenciada, o que os autores observaram foi um processo desordenado de ocupação do território, concentrando nas regiões centrais um grande número de vazios urbanos e nas regiões periféricas, uma densa concentração da população de menor poder aquisitivo.

Reiteraram que, durante a aprovação na Câmara, as alterações sofridas pelo PD de Palmas foram muito prejudiciais ao seu conteúdo. Observaram, ao analisar as ZEIS, que apesar da tentativa do executivo de implantá-las em áreas centrais, a lei aprovada priorizou localizações mais afastadas, reafirmando a lógica de segregação residencial da população de baixa renda nas "franjas da cidade", para que ocorresse valorização dos imóveis centrais subutilizados.

Viera et al. (2013) relatam a experiência vivenciada por alunos e professores do curso de Arquitetura e Urbanismo da Universidade do Vale do Itajaí (Univali) durante os anos de 2011 e 2012, na realização do projeto de extensão e filantropia intitulado "Assessoria aos Gestores Públicos no Processo de Revisão do Plano Diretor de Desenvolvimento Territorial de Camboriú (SC)". A equipe da Univali realizou encontros de capacitação popular, com objetivo de instrumentação para a participação, nos quais foram abordados aspectos relacionados ao Estatuto da Cidade, plano diretor vigente e sua estrutura, macrozoneamento, índices e instrumentos urbanísticos. Nesse sentido, a Universidade desempenhou um papel fundamental na superação do 
desequilíbrio da comunicação entre aqueles detentores do "código" e os que não o possuem (VIEIRA et al., 2013).

Acerca da implantação do Plano Diretor de São Paulo (SP) no ano de 2002, Avritzer (2008) publicou que este diploma legal sofreu forte oposição na Câmara e na Justiça, especialmente no que diz respeito às mudanças de zoneamento e ao aumento de zonas exclusivamente residenciais na cidade. A reação ao plano apareceu de setores conservadores, cujos interesses estavam sendo diretamente afetados pela mudança em certos zoneamentos. Ao final deste processo, o PD de São Paulo foi aprovado com um elevado número de emendas de vereadores que mudavam pequenas configurações do zoneamento na tentativa de atender a interesses pontuais, o que retrata uma sociedade civil dividida e uma sociedade política que necessita da normatização da participação popular para torná-la eficaz.

O processo de implantação do PD em Salvador (BA) também foi descrito por Avritzer (2008). A partir da aprovação do Estatuto da Cidade e da decisão de elaborar o PD, a cidade contratou uma consultoria privada para a elaboração de uma proposta de plano. As associações da sociedade civil ligadas à questão da reforma urbana não foram sequer informadas da atuação de uma consultoria e a publicidade das audiências públicas para o plano. Foi neste contexto que a Federação de Associações de Bairros de Salvador (FABS), alguns movimentos ambientalistas e a Ordem dos Advogados do Brasil (Seção Bahia) formularam representação à Promotoria de Meio Ambiente solicitando que viabilizasse a discussão do Plano Diretor junto às comunidades de Salvador, de acordo com o que determina o Estatuto da Cidade. Nesse intervalo, a prefeitura de Salvador enviou a proposta de lei à Câmara Municipal antes que este debate se viabilizasse, o que obrigou o Ministério Público a entrar com ação na qual pediu a declaração de nulidade da mesma. Ficou claro que o desenho institucional de ratificação atuou impedindo um governo conservador de implantar a sua política urbana sem antes negociá-la com a sociedade civil (AVRITZER, 2008).

Avritzer (2008) diferencia os desenhos institucionais participativos do orçamento participativo e plano diretor municipal em, pelo menos, três aspectos: "na maneira como a participação se organiza; na maneira como o Estado se relaciona com a participação e na maneira como a legislação exige do governo a implementação ou não da participação" (AVRITZER, 2008, p. 44). O orçamento participativo (OP), para Avritzer (2008) apresenta elevada capacidade democratizante, em contrapartida, também alta dependência do sistema político. O Plano Diretor, por outro lado, sob a ótica do referido autor, apresenta baixa capacidade democratizante, porém também baixa dependência do sistema político. Desta forma, ilustrando outro desenho 
institucional participativo, será apresentada brevemente a experiência de Porto Alegre com a implantação do Orçamento Participativo.

Boaventura de Souza Santos (2002), em obra de sua organização, "Democratizar a democracia: os caminhos da democracia participativa", cita a experiência de Porto Alegre, na implantação do orçamento participativo (OP). Conceitua o orçamento participativo promovido pela prefeitura de Porto Alegre como

uma forma de administração pública que procura romper com a tradição autoritária e patrimonialista das políticas públicas, recorrendo à participação direta da população em diferentes fases da preparação e da implementação orçamentária, com uma preocupação especial pela definição de prioridades para a distribuição dos recursos de investimento (SANTOS, 2002, p. 466).

Para o autor, três princípios sustentam o OP: direito de participação assegurado a todos os cidadãos; participação regida por uma combinação de regras de democracia direta e de democracia representativa e distribuição dos recursos de acordo com

um método objetivo baseado em uma combinação de "critérios gerais" critérios substantivos, estabelecidos pelas instituições participativas com vista a definir prioridades - e de "critérios técnicos" - critérios de viabilidade técnica ou econômica, definidos pelo Executivo, e normas jurídicas federais, estaduais ou da própria cidade, cuja implementação cabe ao Executivo (SANTOS, 2002, p. 467).

No contexto de um processo de tomada de decisão baseado em regras gerais e critérios de justiça distributiva, discutidos e aprovados em órgãos institucionais, nos quais, porém, a classe popular tem representação majoritária, o "OP pode ser considerado o embrião de uma democracia redistributiva" (SANTOS, 2002, p. 514).

Entretanto, existem máculas no processo e que foram suscitadas na obra Boaventura (2002). Em apertada síntese, cita o autor que "ter acesso à informação relevante e dominá-la é, provavelmente, a condição básica para o funcionamento efetivo do OP" (SANTOS, 2002, p. 522). Além disso, "o processo de construção do consenso é complexo porque os problemas em discussão, bem como as decisões tomadas, frequentemente apresentam, além da dimensão política, uma acentuada dimensão técnica" (SANTOS, 2002, p. 527). Assim, a discussão de critérios técnicos esbarram no grau de instrução da população. Por outro lado, o sucesso do modelo de OP pode ensejar que, gradualmente, os cidadãos comuns sejam substituídos por cidadãos participativos especializados.

Sendo o OP uma "constelação institucional", devendo encontrar o equilíbrio entre o movimento popular e o governo municipal, a autonomia do OP deve ser pensada como "a capacidade real de os representantes populares nessas instituições moldarem as agendas, os 
prazos, os debates e as decisões" (SANTOS, 2002, p. 534). Pois, no contexto da democracia participativa, exige-se uma transparência entre ação política e resultados muito superior àquela que é típica da democracia representativa. Deste processo, espera-se uma "gestão eficaz das ações de participação; relação direta com os resultados concretos; e da capacidade de "retorno" das estruturas de delegação e representação que emergem no interior da democracia participativa [...]" (SANTOS, 2002, p. 552).

Acrescenta que, perante a competência da Câmara de Vereadores em aprovar o orçamento municipal, o OP estabeleceu um ponto de conflito com este ente, quando se apropriou dessa incumbência.

Santos (2002) infere que a ideia do OP mantém-se sempre entre extremos, de forma que ou é concebida como algo utópico, fadado ao fracasso ou vendida como uma ideia de sucesso, com vistas a agradar o Banco Mundial e facilitar a obtenção de financiamentos, mediante o aceite das intervenções por este propostas, que acabam solapando a concretude do OP. Por isso, Souza (2001) ressalta que não existe um modelo de OP, e sim várias experiências que adquiriram contornos diferenciados e que, talvez por isso o maior risco do OP, esteja na tentativa de copiá-lo.

São experiências únicas, moldadas à luz da realidade fática, tal que a exitosa experiência belo-horizontina ${ }^{9}$ do OP não se compara à porto-alegrense, pois depende fortemente de fatores culturais e sociais. Daí a centralidade do papel do cidadão na construção de desenhos participativos realmente efetivos. Depreende-se o mesmo da implantação do PD participativo; as experiências são diversas e únicas, e deve-se extrair de cada uma delas, lição para um melhoramento contínuo, a cada revisão do texto legal.

Partindo para a análise local, Anilson Russi, no ano de 2014, defendeu dissertação de mestrado intitulada "Entre o legal e o real: a regularização fundiária nos assentamentos urbanos informais do município de Marabá", no Programa de pós-graduação em Dinâmicas Territoriais e

9 Não foi detalhada a experiência do OP em Belo Horizonte. Recomenda-se, entretanto, para aprofundamento de estudos, a leitura dessas obras estudadas pelas autoras: FORTINI, C. A experiência belohorizontina do orçamento participativo como ferramenta para o desenvolvimento local. Revista da Procuradoria-Geral do Município de Belo Horizonte - RPGMBH, Belo Horizonte, ano 4, n. 7, p.57-69, jan./jun. 2011. SAMPAIO, R. C. MAIA, R. C. M. MARQUES, F. P. J. A. Participação e deliberação na internet: Um estudo de caso do Orçamento Participativo Digital de Belo Horizonte, Opinião Pública, Campinas, v. 16, n. 2, p.446477, nov. 2010, HOROCHOVSKI, R.R. CLEMENTE, A. J. A democracia deliberativa e orçamento público: experiências de participação em Porto Alegre, Belo Horizonte, Recife e Curitiba. Revista Sociologia Política, Curitiba, v. 20, n. 43, p. 127-157, out. 2012. CUNHA, M. A. V. C. DA. COELHO, T. R. POZZEBON, M. Internet e participação: o caso do orçamento participativo digital de Belo Horizonte. RAE-Revista de Administração de Empresas, v. 54, n. 3, p. 296-308, mai./jun. 2014. ABREU, J. C. A. PINHO, J. A. G. Sentidos e significados da participação democrática através da Internet: uma análise da experiência do Orçamento Participativo Digital. Revista Administração Pública, Rio de Janeiro, v. 48, n. 4, p.821-846, jul./ago. 2014. 
Sociedade na Amazônia (PDTSA) da Universidade Federal do Sul e Sudeste do Pará (UNIFESSPA). O referido autor realizou um diagnóstico crítico do Plano Diretor Participativo do Município de Marabá (PDPMM) e apontou uma série de peculiaridades e óbices à efetivação dos instrumentos ali previstos.

O Plano Diretor Participativo do Município de Marabá (PDPMM) foi instituído pela Lei Municipal no 17.213 de 09 de outubro de 2006. E, segundo o autor, foi elaborado por uma equipe de profissionais pertencentes à Universidade Federal do Pará (UFPA) e de técnicos da Prefeitura Municipal de Marabá, entre os anos de 2004 e 2006. No diagnóstico inicial do Plano Diretor (MARABÁ, 2008 apud RUSSI, 2014), o município foi classificado como zona de expansão de fronteira urbana, devido ao seu caráter de modificações rápidas e substanciais. O diagnóstico apontou ainda problemas em potencial devido ao crescimento da população em áreas alagáveis, além de demonstrar também a deficiência geral de infraestrutura, de serviços e espaços públicos na área urbana. O foco da pesquisa de Russi foi a regularização fundiária do município, entretanto, o autor teceu algumas críticas ao aspecto "participativo" do referido plano.

O referido diploma legal cria a figura do "Conselho Gestor" no artigo 150, composto (conforme o artigo 152) por 50\% de membros do Poder Público e 50\% de membros da sociedade. O número total de conselheiros é de 30 membros, sendo assim divididos: I) Governo, 15 membros; II) representantes do segmento empresarial urbano e rural, 3 membros; III) representantes dos sindicatos de trabalhadores urbanos e rurais, 3 membros; IV) representante de instituição de ensino e pesquisa, 1 membro; V) representantes de organizações não governamentais, 2 membros; VI) representantes das entidades de classe da área tecnológica, 2 membros e; VII) representantes das associações de moradores e centros comunitários, 4 membros (RUSSI, 2014, p. 61-2).

Pode-se inferir que o Movimento Popular representa, portanto, apenas 13,33\% do total da composição do Conselho Gestor do Plano Diretor de Marabá-PA. Por si só, esta configuração já demonstra uma correlação de forças desigual, em que as entidades representantes dos empresários (rural, urbano e tecnológico), juntos, somam 36,67\% do total de membros (RUSSI, 2014).

O Conselho Gestor e as ferramentas de gestão democrática têm a finalidade de apresentar elementos consistentes ao poder público para o debate de natureza política, econômica e social entre grupos da sociedade organizada. Ocorre que vivemos em uma sociedade de desigualdade sócioespacial, onde uma pequena parcela da sociedade detém o poder político e econômico em detrimento da maioria. Esta minoria, que concentra o poder é quem define as ações no Conselho 
Gestor e a favor dessa minoria está o tecnicismo burocrático. Nesse sentido, "define os encaminhamentos do Conselho Gestor quem domina a técnica burocrática e nem tanto, quem domina a técnica urbanística" (RUSSI, 2014, p. 62-63).

O Plano Diretor de Marabá estabelece ainda a Conferência do Plano Diretor (art. 158), como instância máxima deliberativa. No entanto, segundo Russi (2014, p.63), não tem poder deliberativo sobre questões técnicas, objeto de pareceres de câmaras especializadas. Por outro lado, tem o condão de solicitar revisões e alterações do Plano, bem como deve acompanhar sua execução, em paralelo à atribuição do Conselho Gestor estabelecida na lei.

Russi (2014, p. 65) relata que "a distância entre o que determina o aparato legal e o resultado prático está ligada estreitamente à correlação de forças no âmbito do Conselho Gestor e na administração técnico-político-administrativa da municipalidade". Pensando dessa forma, o autor afirma que PDPMM necessita urgentemente de uma revisão, de forma que o conteúdo do PDPMM e seus métodos devem ser redefinidos de baixo para cima.

Com lastro na pesquisa de Russi (2014), aprofundou-se a avaliação dos do PDPMM, conforme disposto a seguir.

\section{ESTUDO DE CASO}

Poucos municípios elaboraram seus "planos diretores de forma participativa e incorporaram ao seu ordenamento jurídico e institucional instrumentos e espaços de participação popular para construção coletiva da gestão governamental" e esse é um grande desafio a ser enfrentado pelo país: "superar o modelo tradicional de planejamento e gestão" (PRIETO, 2010, p. 51). Além disso, torná-los efetivos, significa ir além da previsão legal dos instrumentos de gestão democrática, e avaliar se esses instrumentos foram regulamentados e implementados.

Nesse contexto, Prieto (2010) aquilatou alguns tópicos para direcionar o estudo de caso do Plano Diretor Participativo de qualquer município, baseado nas disposições do Estatuto da Cidade. Segundo o autor, a partir do estudo desses tópicos é possível avaliar se o processo de elaboração do plano diretor foi participativo.

Para este estudo de caso, a Secretaria Municipal de Planejamento de Marabá (órgão ao qual está ligada a gestão do plano diretor) foi oficiada em 08 de janeiro de 2016, pela Universidade Federal do Sul e Sudeste do Pará, para disponibilizar informações e documentos que pudessem lastrear a pesquisa. Logo, o primeiro entrave encontrado ao desenvolvimento do estudo, foi a dificuldade em se obter informações, pois os dados somente foram disponibilizados após a 8a 
Promotoria de Justiça de Marabá/PA oficiar a referida Secretaria, em junho de 2016, que respondeu parcialmente as informações em 20 de julho de 2016.

Os documentos que foram disponibilizados tratam-se de: 28 atas de posse de membros do Conselho Gestor do PDPMM; ata da reunião extraordinária de 17/10/2014, que empossou os membros; relatório de gestão do ano de 2014; 6 (seis) atas de reuniões ocorridas no ano de 2015; Decreto no 196/2014, que convoca a Conferência do Plano Diretor em 2014; Decreto no 064/2016, que convoca para a 4ạ Conferência Municipal das Cidades; e ata desse evento.

Após a coleta das informações, aplicando-se o método dedutivo, a abordagem consistiu em um confronto entre o que dispõe o EC, o PDPMM e que foi compreendido da realidade local. Assim, parte-se do elemento geral, a norma jurídica, tomada como a premissa verdadeira, para a análise da situação particularizada e, sobre ela, tecer conclusões.

O primeiro tema a ser estudado consiste em avaliar os conselhos de política urbana ou das cidades quanto à representatividade, o caráter deliberativo ou meramente consultivo, aos mecanismos de formação do conselho, se o conselho está ativo e periodicidade das reuniões, com base no caput e no inciso I do artigo 43 do EC, reforçado pelo texto do artigo 45.

O artigo 150 da Lei no 17213/2006 (PDPMM) institui o Conselho Gestor (CG) do Plano Diretor Participativo, "órgão consultivo e deliberativo em matéria de natureza urbanística, política urbana, territorial e habitacional, constituído por representantes do poder público e da sociedade civil” (MARABÁ, 2006).

Das atas de posse extraiu-se que o CG atualmente é formado por 28 membros; 16 são ligados à Prefeitura Municipal, (57,14\%); 3 são representantes do setor industrial, comercial e rural; 1 representante de ONG; 1 representante da academia (UNIFESSPA); 2 representantes de entidades de classe e 5 representantes de associações de moradores e centros comunitários $(17,85 \%)$, dentre os 16 distritos administrativos listados no artigo 60 do PDPMM.

É previsto ainda no artigo 155 da referida lei, a formação dos Conselhos Distritais nos distritos administrativos da zona rural, com o fito de discutir prioridades para os distritos, o que ainda não foi efetivado. No artigo 156 menciona-se que estes terão objetivos e atribuições definidos em um regimento interno, a ser elaborado. Quanto à inexistência desses conselhos, a Secretaria reconhece que não se encontram implantados e que se trata de um ponto sensível a ser trabalhado na revisão do PDPMM. 
Salta aos olhos a baixa representatividade das associações de moradores e centros comunitários na formação do CG, em uma razão de 5 membros representando 16 distritos administrativos (art. 60, inciso I-XVI, PDPMM).

Não é somente preocupante a falta de representatividade das associações e centros comunitários constatada de fato, como o desequilíbrio de forças já previsto na norma. Segundo o artigo 152, inciso II, alínea "h", da Lei no 17213/2006, compõe o Conselho Gestor apenas 4 representantes desse segmento É imperioso que se amplie a representatividade dos populares, desde já, no próprio texto legal.

Note-se também que, de fato, a representatividade dos membros ligados ao Executivo municipal excede a metade dos membros, contrariando o previsto no artigo $152^{10}$.

As eleições para formação deste Conselho são realizadas bianualmente na Conferência Municipal das Cidades (denominação dada à Conferência do Plano Diretor, artigo 160, II, PDPMM). É definida como a instância máxima de decisão do Conselho Gestor do Plano Diretor e terá a participação da população (artigo 158, caput, PDPMM)

Os atuais conselheiros foram eleitos no ano de 2014 e, conforme o artigo 150 do PDP, § 2으, têm mandato de dois anos, sem direito à reeleição. O que é louvável, pois evita o surgimento de "conselheiros profissionais".

No ano de 2015, foram realizadas 6 (seis) reuniões segundo as atas recebidas, resultando numa frequência bimestral. O conteúdo das atas de reuniões revela momentos de caráter deliberativo, o que é reflexo do alto percentual de conselheiros ligados à própria Prefeitura, inclusive com a participação do Secretário de Planejamento em reuniões. Pergunta-se, até que ponto a autonomia do CG é favorável aos interesses da população? Uma vez que, para que a prioridade das discussões corresponda às prioridades da população, é necessário equilíbrio de forças na composição deste conselho.

Porém, o conteúdo das discussões está aquém das atribuições legais deste Conselho, dispostas no artigo 151, entre elas acompanhar a implementação do Plano Diretor Participativo; convocar, organizar e coordenar as audiências públicas, conferências, assembleias temáticas e territoriais; propor à Conferência do Plano Diretor regimentos internos, planos, programas e projetos de interesse urbano e territorial sustentável; opinar sobre projetos de leis de interesse da

${ }^{10}$ Art. 152. O Conselho Gestor do Plano Diretor será composto por conselheiros eleitos pelos delegados por ocasião das Conferências do Plano Diretor, por uma Secretaria Executiva e pelas Conferências do Plano Diretor. $\S 10$. O Conselho Gestor do Plano Diretor é composta por 30 (trinta) membros não remunerados, de acordo com o que segue: I. Representantes do Poder Executivo Municipal e seus respectivos suplentes, indicados pelo Prefeito Municipal em número de 15 (quinze), assim discriminados: (MARABÁ, 2006). 
política urbana e territorial municipal, Lei do Plano Diretor, Lei do Plano Plurianual, Lei de Diretrizes Orçamentárias e Lei Orçamentária Anual, antes de seu encaminhamento à Câmara Municipal e facilitar o acesso da população do município a documentos, planos e projetos elaborados pelo Poder Executivo e Legislativo, referentes à política urbana do município.

Limitada à leitura das atas das seis reuniões realizadas em 2015, verifica-se a inócua participação dos conselheiros representantes de associações de moradores. Verifica-se maior atividade dos conselheiros em assuntos bastante pontuais, tais como uma intensa problemática a respeito da instalação de um supermercado, que afetou bastante os bairros contíguos, na localidade denominada de "Folha 33", discutida na ata de 24/09/2015. Deduz-se do conteúdo descrito na ata, a existência de divergências entre o projeto aprovado e o projeto construído do supermercado, o que causou transtornos à população do entorno do empreendimento.

O que, aliás, é tema recorrente nas atas: os transtornos que empreendimentos vem causando ao espaço urbano e a esparsa influência do Conselho Gestor na autuação dos mesmos, colocando em xeque o disposto no artigo 151, § 1으, quanto à obrigatoriedade de consulta da população diretamente atingida, mediante a realização de audiências públicas, para implantação de obras e projetos que podem ocasionar grande impacto ambiental ou de vizinhança.

Do material analisado, constatou-se que pouco se discute sobre a apropriação do espaço urbano, a efetivação do direito à cidade ou mesmo sobre a efetividade dos instrumentos do Plano Diretor para assegurar o cumprimento dos princípios constitucionais sobre a política urbana e sobre o disposto no Estatuto da Cidade. Ademais, esse Conselho, que deveria representar uma abertura a participação democrática, mostrou-se extremamente burocratizado, com a frequente formação de subcomitês e grupos quando surgem impasses nas reuniões.

O art. 40, § 4으, inciso I do EC combinado com o art. 43, inciso III, reforça a necessidade de debates, audiências e consultas públicas e conferências sobre assuntos de interesse urbano, com a participação da população, associações e vários segmentos da comunidade, no processo de elaboração e fiscalização do PD e para assegurar a gestão democrática da cidade. Baseado nestes dispositivos, avaliou-se as conferências sobre assuntos de interesse urbano quanto à existência de regulamentação; o caráter deliberativo ou meramente consultivo; se há participação da sociedade e a quantidade de conferências já realizadas.

Quanto à regulamentação de conferências, existe a previsão legal da ocorrência anual da Conferência Municipal das Cidades, convocada por decreto e de caráter deliberativo. Neste evento são definidas linhas mestras para a política urbana; também têm atribuição para criticar e propor 
ações ao CG e eleger seus membros, bem como, criticar e propor alterações à lei que institui o PD. Toda a sociedade é convidada a participar e é feita a divulgação no sítio da prefeitura e rádios da cidade.

No ano de 2016, a conferência ocorreu entre 04 a 06 de maio, e segundo registro em ata, foram dados os seguintes encaminhamentos:

I. Sobre os novos empreendimentos, conjecturou-se a obrigatoriedade de projeto arquitetônico, o memorial descritivo de calçadas, com observância da NBR 9050/2015 ("Acessibilidade a edificações, mobiliário, espaços e equipamentos urbanos"), com vistas à acessibilidade de pessoas com deficiência e exigência do estudo de impacto de vizinhança, que já é previsto no PDPMM.

II. Quanto ao transporte urbano, deliberou-se sobre a necessidade de revisão das concessões e reelaboração da distribuição dos meios de transporte coletivos urbanos e criação de um terminal de integração do transporte coletivo.

III. Quanto à política urbana, votou-se pela efetivação da regularização fundiária e sobre a transferência de titularidade para o município de áreas urbanas pertencentes ao Estado e União, que se encontram no âmbito do município.

IV. Por último, quanto ao saneamento básico, discutiu-se a obrigatoriedade de investimentos públicos para o setor em 5\% do Produto Interno Bruto do município.

Pode-se inferir, das atribuições da Conferência descritas no PDPMM, e previsão legal de atuar como instância máxima de decisão do Conselho Gestor do Plano Diretor, que a Conferência Municipal das Cidades poderia aprofundar-se mais na discussão com a sociedade, ampliar os canais de comunicação e fortificar os já existentes, a exemplo do que dispõe o inciso IV, sobre opinar a respeito do Plano Plurianual, Lei de Diretrizes Orçamentárias e Orçamento Municipal, matéria que não foi tratada nesse evento.

E também, verificou-se que a pauta deliberada durante a Conferência não foi sequer mencionada durante o restante das reuniões do Conselho Gestor ocorridas em 2016. A falta de acompanhamento dessas deliberações constitui um grande óbice à abertura a democracia participativa proposta no EC, pois o cidadão não vê qualquer reflexo positivo de seu esforço para inserir-se nos "assuntos do palácio", mitigando seu anseio de participar de processos decisórios referentes à ocupação do solo urbano. Ao longo da existência dos 10 anos de existência do PDPMM, já foram realizadas 6 (seis) conferências. 
Novamente, o artigo 40, § 4으, inciso I combinado com o artigo 43, inciso II, ambos do EC, instam pela realização de debates, audiências e consultas públicas, que devem ser avaliados quanto à existência de regulamentação (com previsão das hipóteses em que deve ocorrer e quem pode requerê-las); caráter deliberativo ou meramente consultivo; se há participação da sociedade e as formas de participação; além quantidade de vezes que já foram realizados.

A atribuição de convocar debates, audiências e consultas públicas está prevista no artigo 151, inciso III, e pertence ao Conselho Gestor, majoritariamente composto pelo Poder Público. De tal modo, os representantes populares necessitam de apoio de outros membros até mesmo para alcançar o quórum simples, para solicitar a realização de um evento desse porte.

Não existem registros de que tenha ocorrido alguma convocação no ano de 2015, impossibilitando de avaliar quesitos, tais como caráter deliberativo ou meramente consultivo ou se há participação da sociedade e as formas de participação.

Existe uma previsão específica e regulamentada no âmbito do PD de convocação de audiência pública, relativa à obrigatoriedade de consulta à população sobre empreendimento gerador de impacto. Nessa hipótese, a audiência tem caráter deliberativo, e é necessária a participação da sociedade. Não são informados dados como quórum para realização da mesma ou formas de convocação.

Em Ofício, a Secretaria de Planejamento mencionou que não houve empreendimento gerador de impacto analisado em 2015. Contradizendo este dado, a ata de 28 de janeiro de 2015 mostra a aprovação de um empreendimento, a saber, um cemitério. E não é mencionada a consulta à população. Relativo ao ano de 2014, o relatório de gestão cita os empreendimentos geradores de impactos que estiveram sujeitos à aprovação do CG. Foram analisados 12 (doze) empreendimentos, mas não fica demonstrada a consulta à população.

Assim, resta a Conferência das Cidades, enquanto evento em que o cidadão comum pode se pronunciar. Entretanto, sem o condão de deflagrá-la e com frequência anual, apenas.

Assim como estudou-se a convocação de conferências, consultas, audiências e debates públicos, importa ponderar sobre a abertura à iniciativa popular de projeto de lei e de planos, programas e projetos de desenvolvimento urbano no contexto do PD. Estes devem ser avaliados quanto à existência de regulamentação, com a previsão das hipóteses em que devem ocorrer, as formalidades para os requerimentos, os legitimados a requerê-las e prazos para análises.

O ambiente do PDPMM é um tanto incipiente quanto à iniciativa popular de projetos. Basicamente, é atribuição do Conselho Gestor esse tipo de iniciativa. Com um comitê bastante 
burocratizado, o cidadão não dispõe de instrumentos para ser o protagonista desse processo. Restam proposições que possam ser feitas na Conferência do Plano Diretor ou tentativas de inserir na pauta das reuniões do CG esse tipo de proposta, por meio dos escassos conselheiros representantes dos bairros e associações.

As interferências via Conferência do Plano Diretor estão previstas no artigo 160 do PDPMM, como opinar sobre o Plano Plurianual, a Lei de Diretrizes Orçamentárias e o Orçamento municipal, propor ao Executivo mudanças em ações estratégicas destinadas a implementação de planos, programas e projetos setoriais de acordo com o PDPMM, bem como propor alterações ao próprio plano diretor e na legislação afim à Política Municipal de Desenvolvimento.

Entretanto, conforme já foi mencionado, as conferências não estão estruturadas de maneira que os encaminhamentos nela ocorridos sejam acompanhados. É preciso que as atas das Conferências sejam acompanhadas pelo CG e pela própria população, sob pena de esvaziamento do propósito do evento.

O Estatuto da Cidade preceitua em seu artigo 44, que no âmbito municipal, a gestão orçamentária incluirá a realização de debates, audiências e consultas públicas sobre as propostas do plano plurianual, da lei de diretrizes orçamentárias e do orçamento anual, como condição obrigatória para sua aprovação pela Câmara Municipal. Baseado neste dispositivo, necessita-se avaliar se há regulamentação em lei ou decreto e se ocorrem as audiências públicas para elaboração dos projetos das leis do ciclo orçamentário (LDO, LOA e PPA) e verificar se o município permite consulta pública da população aos projetos e às leis orçamentárias, bem como a execução das despesas por programas governamentais, principalmente pela internet.

O município não implantou audiências públicas para elaboração dos projetos das leis do ciclo orçamentário (LDO, LOA e PPA) no âmbito do Plano Diretor. Apenas delega a competência à Conferência do PD para discutir essas matérias (artigo 158, inciso IV, PDPMM), que conforme exposto, não foi tratado na Conferência de 2016.

Tendo em vista a transparência da gestão, o sítio da Prefeitura (http://transparencia.maraba.pa.gov.br/) disponibiliza acesso às leis orçamentárias; às receitas e despesas do município; despesas com pessoal e diárias; recursos federais recebidos; contratos, convênios, fornecedores e licitações; órgãos, gestores, programas, ações, projetos e legislação municipal.

Para finalizar, no artigo 40, §4, expõe-se que no processo de elaboração do plano diretor e na fiscalização de sua implementação, os Poderes Legislativo e Executivo municipais garantirão a 
publicidade quanto aos documentos e informações produzidas e o acesso de qualquer interessado aos documentos e informações produzidos.

Bem como, o artigo 42 (EC) aduz que o Plano Diretor deve conter, no mínimo, um sistema de acompanhamento e controle. Nesse sentido que a implantação de um sistema de informações municipais deve ser verificada, especialmente se há previsão legal do sistema, se há critérios e prazos para disponibilização de documentos públicos à população e se o portal da Prefeitura na internet permite o acesso a informações municipais, às leis urbanísticas e mapas do plano diretor e sobre as contas públicas.

É previsto na lei municipal que institui o Plano Diretor (artigo 163, PDPMM) um sistema de informações municipais, porém ainda não implantado. Entretanto, no sítio da Prefeitura existem muitas informações disponíveis aos munícipes, conforme já mencionado. Foi localizado também na rede mundial o Plano Diretor de Marabá, Plano Local de Habitação de Interesse Social, convocação para reuniões e conferências, entre outras publicações relevantes.

Um importante instrumento previsto no PDPMM, o relatório de gestão (art. 154, PDPMM) deve ser citado, pois tem o desígnio de dar transparência e publicidades às atividades do CG. Contudo, até 20 de julho de 2016, não estava disponível o relatório de gestão do exercício de 2015, que deve conter também, em caráter informativo, o plano de ação para o ano de 2016. Dessa forma, tampouco se pode discutir sobre a necessária publicidade desse documento e formas de divulgação.

\section{CONSIDERAÇÕES FINAIS}

Demonstrou-se por meio da revisão bibliográfica, a importância da experimentação de novas formas de democracia, relacionando-se aos princípios fundantes do ordenamento jurídico brasileiro, a saber, a cidadania e a dignidade da pessoa humana.

Essa necessária relação também é estimulada no Estatuto da Cidade e está refletida em seus instrumentos para gestão democrática participativa do ambiente urbano e acompanhamento e fiscalização do Plano Diretor. Busca-se, por meio da autonomia (refletida na dignidade da pessoa humana) e exercício da cidadania, a possibilidade de influenciar na construção de ambientes urbanos mais justos e democráticos, quiçá atravessar as fronteiras da desigualdade sócioespacial e efetivar o direito à cidade, cujo conteúdo valorativo é um vazio a ser preenchido coletivamente.

Demonstrou-se, também, através dos relatos de implantação do Plano Diretor em vários municípios brasileiros, que o caminho a ser trilhado é árduo. Os princípios da democracia 
representativa estão fortemente enraizados na cultura brasileira. Entretanto, os vários óbices encontrados à efetivação de instrumentos participativos só surgiram devido à tentativa de concretizá-los. Por isso, para o que o horizonte de efetivação do direito à cidade seja alcançado, é imperioso não recuar.

Nesse sentido, este estudo de caso tornou bastante evidente que a previsão de vários instrumentos participativos no Plano Diretor não condiz com o que dispõe o Estatuto da Cidade. E o que de fato está implantado, ainda está aquém da previsão legal no PD local.

Citou-se em várias passagens que as atribuições legais do Conselho Gestor do Plano Diretor vão muito além de sua real atuação. Possivelmente a formação, majoritariamente composta por representantes do Poder Público, tolha o funcionamento deste em sua plenitude. Falta-lhe representatividade popular para ensejar a movimentação em torno de temáticas que são prioritárias para as grandes massas, e vão de encontro à lógica de mercado capitalista e interesses escusos que, por vezes, movem as forças políticas.

Dessa forma, com sua formação preponderantemente ligada à Administração municipal, o CG não cumpre sua função de disseminar a experiência da democracia participativa. Pelo contrário, desvirtuado, transforma-se em mais um braço da Administração, mergulhado na burocracia.

Ressalte-se também que, sem a formação dos conselhos distritais, aliada à baixa representatividade popular no CG e a ausência de instrumentos voltados ao cidadão para deflagrar debates, audiências ou consultas públicas, ou mesmo a iniciativa popular de leis e projetos, fica bastante limitada a participação das comunidades na gestão municipal. Não se cumpre, pois, os objetivos da política urbana contidos no Estatuto da Cidade, relativos à inclusão de vários setores da sociedade na gestão democrática da cidade. Nem mesmo a audiência obrigatória de consulta à população quanto à autorização para instalação de empreendimentos geradores de impactos tem feito parte das rotinas administrativas (no mínimo, não foi demonstrada sua ocorrência nos documentos fornecidos).

Frise-se ainda que, a principal atribuição legal do CG e da Conferência das Cidades que poderia influenciar bastante nos rumos da gestão urbana, direcionando a atividade política para as prioridades eleitas pela população e promovendo motivação para que os munícipes se engajassem nos processos decisórios, seria a possibilidade de discussão dos projetos de Lei do Plano Plurianual, a Lei de Diretrizes Orçamentárias e a Lei Orçamentária Anual, devido seu alto poder democratizante. O que ainda é apenas letra fria da lei. 
O empoderamento também passa pela publicidade dos documentos e compartilhamento de informações. Os munícipes têm direito à elas e à Administração cabe o dever de ser transparente com seus administrados. Quanto aos relatórios de gestão, principal instrumento que dá publicidade aos atos do Conselho Gestor do PDPMM, peca-se na publicidade e no tempo hábil de distribuição. É imperativo implantar, efetivamente, um canal de comunicação com a sociedade para atrair o interesse dos cidadãos. Afinal, como se interessar por algo que se desconhece?

A abertura à democracia participativa também é ferida mortalmente quando é afetada em sua credibilidade, tal qual ocorre com a Conferência das Cidades. Embora haja envolvimento da sociedade e sejam geradas atas com deliberações, o Conselho Gestor do PD não exerce pressão sobre o Poder Executivo para atendimento ao que foi deliberado no evento.

Lamentavelmente, demonstrou-se que o Plano Diretor Participativo do município de Marabá não efetivou plenamente nem mesmo os instrumentos participativos nele contidos, tampouco atende, com a necessária amplitude, às disposições do Estatuto da Cidade. Espera-se que estas observações possam ser levadas em consideração, em futura revisão desta lei decenária e possibilite maior interação com os cidadãos na construção de um novo Plano, que reflita as necessidades da população e da cidade.

\section{REFERÊNCIAS}

AMARAL, C. T. G.; GUIMARÃES, M. C.; DAUMERIE, R. Democracia participativa brasileira: as audiências públicas como instrumento participativo - a câmara dos vereadores da cidade do Rio de Janeiro. Revista de Direito da Cidade, Rio de Janeiro, v.7, n.2, p.804-844, jun. 2015.

ASSUNÇÃO, M. C. Administração pública democrática e orçamento participativo. Fórum de Contratação e Gestão Pública - FCGP, Belo Horizonte, ano 12, n. 144, p. 47-55, dez. 2013.

AVRITZER, L. Instituições participativas e desenho institucional: algumas considerações sobre a variação da participação no Brasil democrático. Opinião Pública, v. 14, n. 1, p. 43-64, jun. 2008.

Modelos de Deliberação Democrática: uma análise do orçamento participativo no Brasil. In: SANTOS, B. DE S. (org.), Democratizar a democracia: os caminhos da democracia participativa. Rio de janeiro: Civilização Brasileira, 2002, p. 561-597.

BOBBIO, N. O Futuro da Democracia: uma defesa das regras do jogo. São Paulo: Paz e Terra, 1997.

BRASIL. Estatuto da Cidade. Lei 10.257, de 10 de julho de 2001. Regulamenta os arts. 182 e 183 da Constituição Federal, estabelece diretrizes gerais da política urbana e dá outras providências. Brasília, Câmara dos Deputados, 2001.

Constituição (1988). Constituição da República Federativa do Brasil. Brasília, 1988. 
Estatuto da Metrópole. Lei 13.089, de 12 de janeiro de 2015. Institui o Estatuto da Metrópole, altera a Lei no 10.257, de 10 de julho de 2001, e dá outras providências. Brasília, Câmara dos Deputados, 2015.

CORIOLANO, G. P. RODRIGUES, W. OLIVEIRA, A. F. Estatuto da Cidade e seus instrumentos de combate às desigualdades socioterritoriais: o Plano Diretor Participativo de Palmas (TO). Revista Brasileira de Gestão Urbana, v. 5, n. 2, p. 131-145, jul./dez. 2013.

DAHL, R. A. Sobre a Democracia. Brasília: UnB, 2001.

DAVIS, M. Planeta Favela. São Paulo: Boitempo, 2006.

DIAS, D. M. S. Democracia Urbana: É possível coadunar desenvolvimento sustentável e práticas democráticas nos espaços urbanos no Brasil? Curitiba: Juruá Editora, 2010.

Planejamento e Desenvolvimento Urbano no Sistema Jurídico Brasileiro - Óbices e Desafios. Curitiba: Juruá Editora, 2012.

FONSECA, L. G. D. BELÉM, M. A. P. SILVA, S. N. T. S. A Educação Jurídica Popular como Instrumento do Direito à Gestão Democrática da Cidade: a Prática Extensionista na Busca por uma Participação Popular Efetiva. In: SAULE JR. N. et al (org.). Anais do V Congresso Brasileiro de Direito Urbanístico: O Direito Urbanístico nos 20 anos da Constituição Brasileira de 1988 - Balanço e perspectivas. Porto Alegre: Magister, 2009.

HARVEY, David. Cidades rebeldes: do direito à cidade à revolução urbana. São Paulo: Martins Fontes, 2014.

MARABÁ. Plano Diretor Participativo do Município de Marabá. Lei 17.213, de 2006. Marabá, Câmara dos Vereadores, 2006.

MARQUES, D. G. G. ALVES, T. F. A voz popular e a voz do governo: um estudo sobre o conselho do orçamento participativo de Campina Grande - PB, Brasil. Livro de Atas do 10 Congresso da Associação Internacional de Ciências Sociais e Humanas em Língua Portuguesa, v.1, 2015.

MEIRELLES, D. R. S. GOMES, L. C. M. Cidades, processo e participação: legitimidade das associações na tutela coletiva urbanística. Revista Direito da Cidade, Rio de Janeiro, v. 2, n. 1, p. 164-189, 2007.

NAKANO, K. A persistência da participação cidadã no planejamento e na gestão urbana. In: COELHO, L. X. P. (org.), O mito do planejamento urbano democrático: reflexões a partir de Curitiba. Curitiba: Terra de Direitos, 2015, 152 p.

OSCAR JR., A C. S. Avaliação da conformidade do plano diretor duquecaxiense: subsídios para a compreensão das cidades (não) resilientes. Revista Direito da Cidade, Rio de Janeiro, v. 6, n. 2, p. 301-322, 2014.

PRIETO, E. C. O plano diretor participativo como instrumento de gestão democrática e fortalecimento do poder local. Fórum de Direito Urbano e Ambiental - FDUA, Belo Horizonte, ano 9, n. 53, p. 40-50, 2010. 
PURCELL, M. The right to the city: the struggle for democracy in the urban public realm. Policy\&Politics, Bristol, v. 43, n. 3, p. 311-327, 2013.

ROLNIK, Raquel. O que é cidade. 4. Ed. São Paulo: Brasiliense, 2012.

RUSSI, Anilson. Entre o legal e o real: a regularização fundiária nos assentamentos urbanos informais do município de Marabá. 2014. 118f. Dissertação (mestrado) - Universidade Federal do Sul e Sudeste do Pará, Marabá, 2014.

SADER, E. Para outras democracias. In: SANTOS, B. DE S. (org.), Democratizar a democracia: os caminhos da democracia participativa. Rio de janeiro: Civilização Brasileira, 2002, p. 649-679.

SANTIN, J. R. MATTIA, R. Q. Direito Urbanístico e Estatuto das Cidades. Revista de Direito Imobiliário, v. 63, p.38-48, jul. 2007.

SANTOS, B. DE S. Orçamento Participativo em Porto Alegre: para uma democracia redistributiva. In: SANTOS, B. DE S. (org.), Democratizar a democracia: os caminhos da democracia participativa. Rio de janeiro: Civilização Brasileira, 2002, p. 455-560.

SANTOS, B. DE S.; AVRITZER, L. Para ampliar o cânone democrático. In: SANTOS, B. DE S. (org.), Democratizar a democracia: os caminhos da democracia participativa. Rio de janeiro: Civilização Brasileira, 2002, p. 39-82.

SANTOS, N. L.; FARIA, C. C. S.; ARAUJO, M. M. Direito à Moradia: os Planos Diretores da RMBH Aplicam o Estatuto da Cidade e a Constituição Federal de 1988? In: SAULE JR. N. et al (org.). Anais do V Congresso Brasileiro de Direito Urbanístico: O Direito Urbanístico nos 20 anos da Constituição Brasileira de 1988 - Balanço e perspectivas. Porto Alegre: Magister, 2009.

SILVA, J. A. da. Concessão de uso especial para fins de moradia: Instrumento de efetividade dos direitos sociais à moradia e à cidade sustentável? 2006. 231f. Dissertação (mestrado) - Pontifícia Universidade Católica, Belo Horizonte, 2006.

SOUZA, C. Construção e consolidação de instituições democráticas: papel do orçamento participativo. São Paulo em Perspectiva, v. 15, n. 4, p. 84-97, 2001.

TRINDADE, Thiago Aparecido. Direitos e cidadania: reflexões sobre o direito à cidade. Lua Nova, São Paulo, n. 87, p. 139-165, 2012.

VIANA, C. R. C. A formação concertada de políticas públicas urbanísticas e o exemplo das operações urbanas consorciadas. Revista dos Tribunais Online, São Paulo, v. 5, mar. 2014.

VIEIRA, R. et al. Participação popular no processo de planejamento urbano: a universidade como "decodificadora" de um sistema de muitos códigos. Revista Brasileira de Gestão Urbana, v. 5, n. 2, p. 115-130, jul./dez. 2013.

Trabalho enviado em 03 de janeiro de 2017.

Aceito em 26 de março de 2017. 